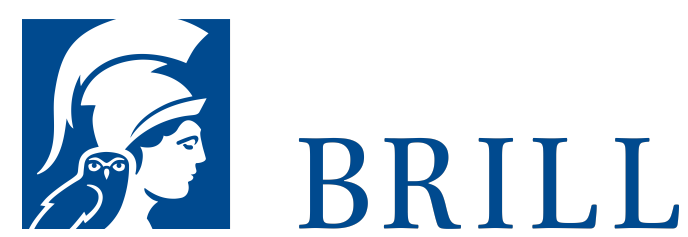

\title{
Marriage and matrimonial property in ancient Egypt
}

Author: P.W. Pestman

\section{Language:}

English

Subjects:

General,

Classical Studies

Publisher: Brill

\section{Series:}

Papyrologica

Lugduno-

Batava, Volume:

\section{9}

E-Book (PDF)

Released online: O2 Mar 2020

ISBN: 978-9004-42999-4 List price USD $\$ 42.00$

\section{Hardback}

Publication date: o1 Jun 1961 ISBN: $978-90-$ 04-42884-3 
For more information see brill.com

Order information: Order online at brill.com +44330 333 0049 | customerservices@brill.com Submission information: brill.com/authors

Titles published by Brill | Fink, Brill | mentis or Brill | Schöningh: +49(o)715413279216| brill@brocom.de 